\title{
Isolation of rat gonocytes by velocity sedimentation at unit gravity
}

\author{
F. M. F. van Dissel-Emiliani* $\ddagger$ D. G. de Rooij† and M. L. Meistrich* \\ *Department of Experimental Radiotherapy, University of Texas, M.D. Anderson Cancer Center, \\ Texas Medical Center, Houston, Texas 77030, USA; and \\ $\dagger$ Department of Cell Biology, Medical School, University of Utrecht, 3584 CL Utrecht, \\ The Netherlands
}

\begin{abstract}
Summary. A method for obtaining enriched populations of gonocytes from rat embryos at 18 days p.c. has been developed. Single cell suspensions with high cell yield and good viability of the cells were obtained by a collagenase/trypsin digestion of the testes. Cells were separated on the basis of size by the Staput technique of velocity sedimentation at unit gravity. Populations of 600000 gonocytes ( $70-75 \%$ purity), sedimenting at about $12 \mathrm{~mm} / \mathrm{h}$, could be obtained from $30-35$ fetal rats within $8 \mathrm{~h}$ after killing. Purities were determined by Nomarski microscopy and verified in fixed preparations and by Coulter volume measurements.
\end{abstract}

\section{Introduction}

In mammals, testicular development begins with the migration of the primordial germ cells from the gut to the genital ridges. This is followed by a period in which the primordial germ cells and their daughter cells, the gonocytes, actively divide. In the rat, the gonocytes become arrested in the $\mathrm{G}_{1}$ phase of their cell cycle at Day 17 to 18 post coitum (p.c.) and do not resume division until after birth (Sapsford, 1962; Franchi \& Mandl, 1964; Huckins \& Clermont, 1968; Hilscher et al., 1974). The postnatal divisions of the gonocytes give rise to the A spermatogonia. There is disagreement regarding the nature of the gonocytes. Hilscher et al. (1974) consider the gonocytes to be specific for the embryonic testis and named them multiplying- and transitional prospermatogonia. On the other hand, Kluin \& de Rooij (1981) have pointed to the fact that the gonocytes, kinetically as well as morphologically, closely resemble the undifferentiated type A spermatogonia observed in the adult testis.

Very little is known about the factors regulating the proliferation and post-natal differentiation of the gonocytes and the undifferentiated spermatogonia. The isolation of a homogeneous population of gonocytes would provide the material needed to perform biochemical studies on these cells and to investigate the regulatory factors. This will lead to a better understanding of the nature of the gonocytes and possibly the stem spermatogonia of the adult testis as well.

Methods described for the successful isolation of highly purified populations of spermatogenic cells from adult and immature rodent testes include velocity sedimentation at unit gravity (Staput), centrifugal elutriation, equilibrium density centrifugation and flow cytometric cell sorting, as well as combinations of these methods (for review see Meistrich, 1977). Although the isolation of primordial germ cells (De Felici \& McLaren, 1982; McCarrey et al., 1987) and of primitive type A spermatogonia (Bellve $e t$ al., 1977) has been described, there are no reports on the isolation of gonocytes. In this study we tested the possibility of using newborn and 18-day fetal rat testes as starting material for the isolation of gonocytes, since at these ages the number of gonocytes per

†Present address: Department of Cell Biology, Medical School, University of Utrecht, Yalelaan 1, PO Box 80.157, 3508 TD Utrecht, The Netherlands. 
testis is maximal (Huckins \& Clermont, 1968). Velocity sedimentation at unit gravity of testicular cells from fetal rats seemed the method of choice for obtaining highly enriched populations of gonocytes.

\section{Materials and Methods}

Animals. Newborn and timed-pregnant Sprague-Dawley male rats were purchased from Harlan Sprague-Dawley (Houston, TX, USA; and Indianapolis, IN, USA). Typically, 10 newborn or 30-35 fetal male rats (5-6 pregnant females) were used for each experiment.

Reagents. Collagenase (Type IV, $197 \mathrm{U} / \mathrm{mg}$ ), hyaluronidase ( $465 \mathrm{U} / \mathrm{mg})$, trypsin (180 U/mg) and soybean trypsin inhibitor (1 mg inhibits $1.28 \mathrm{mg}$ trypsin) were purchased from Worthington Biochemicals (Freehold, NY, USA). DNase (DN-25; $800 \mathrm{U} / \mathrm{mg}$ ) and bovine serum albumin (BSA: Cohn fraction V) were purchased from Sigma Chemical Co. (St Louis, MO, USA).

Collection of the testes. A dissection microscope was used for the collection of fetal and newborn testes. All testes were kept on ice in modified McCoy's medium during the dissection of the animals. To permit effective enzyme treatment, newborn testes were decapsulated, whereas a slit was made in the testes of fetal rats because decapsulation was too difficult to achieve.

Preparation of the cell suspension. A modification of the procedure described by Bucci et al. (1986) was used: $1 \mathrm{ml}$ McCoy's medium was used for $30 \mathrm{mg}$ testis tissue. All incubations were done in a gyratory $(120 \mathrm{cycles} / \mathrm{min})$ water bath at $37^{\circ} \mathrm{C}$. The testes were first incubated in collagenase $(150 \mathrm{U} / \mathrm{ml})$ and hyaluronidase $(120 \mathrm{U} / \mathrm{ml})$ for $30-40 \mathrm{~min}$. They were then centrifuged at $50 \mathrm{~g}$ for $10 \mathrm{~min}$ and further incubated in new medium with trypsin $(198 \mathrm{U} / \mathrm{ml})$ and DNase $(120 \mathrm{U} / \mathrm{ml})$ usually during $40-60 \mathrm{~min}$. After digestion with trypsin, fetal bovine serum ( $8 \%$ final), soybean trypsin inhibitor $(0 \cdot 1 \%$ final), and DNase ( $120 \mathrm{U} / \mathrm{ml}$ final) were added. The cells were then gently dispersed with a pipette (2 or 3 times) and filtered through 80 - and $25-\mu \mathrm{m}$ screens. The cell concentration, the viability of the cells (by trypan blue dye exclusion) and the percentage of gonocytes were then determined.

Cell separation. Cells were separated by velocity sedimentation at unit gravity (Staput) (Meistrich, 1977), in a custom-built chamber (inner diameter of the cylindrical part $=3.9 \mathrm{~cm}$ ) designed for separating small numbers of cells $\left(<10 \times 10^{6}\right)$. To minimize the formation of clumps, 5 mm-naphthol disulphonic acid was added to the cell suspension (Meistrich, 1977), and, furthermore, the cell suspension was not centrifuged before loading it on the gradients. The chamber was filled with $2 \mathrm{ml}$ phosphate-buffered saline $(0 \cdot 1 \mathrm{M}, \mathrm{pH} 7 \cdot 4)$, followed by $2 \mathrm{ml}$ cell suspension and $50 \mathrm{ml}$ of a $2-4 \%$ BSA (containing $5 \mathrm{~mm}$-naphthol disulphonic acid) gradient, up to $4 \mathrm{~cm}$ above the cone of the chamber. Loading and unloading of the chamber took about $6 \mathrm{~min}$. After allowing $2 \mathrm{~h}$ for the sedimentation of the cells, $2 \mathrm{ml}$ fractions were then collected and analysed. Fraction ' 0 ' was the fraction in which the last 3 or $4 \mathrm{ml}$ of the fluid from the Staput chamber was collected.

Cell counting. After separation of the cells, cell counts were performed with a Coulter counter. The volume cut-off of the smallest particles recorded by the Coulter counter was $71 \mu \mathrm{m}^{3}$; no upper level discrimination was used.

Cell identification. Each fraction from the Staput chamber was analysed for the percentage of gonocytes by Nomarski interference microscopy. The cells were also analysed for their volume distribution using a multichannel pulse height analyser coupled to a Coulter counter (Bucci et al., 1986). Absolute volumes were determined with calibrated latex particles (Coulter).

The following criteria were used for identifying the gonocytes by Nomarski microscopy: large round cells with well defined cytoplasmic outlines, a spherical nucleus and a high nuclear to cytoplasmic ratio, a sharp nuclear membrane, several (1-3) relatively large nucleoli, and many cytoplasmic inclusions (Hilscher, 1981), mostly concentrated at one side of the cell. A comparison was made between the morphology of isolated gonocytes identified by Nomarski microscopy with that of isolated gonocytes that were fixed in Bouin's solution, embedded in glycol methacrylate and stained with haematoxylin, and the morphology of gonocytes in testis sections of fetal or newborn rats. The features of isolated gonocytes in section again included sharp cytoplasmic outlines, high nuclear to cytoplasmic ratio, nuclei with dusty to granulated chromatin, and several prominent nucleoli (1-3).

\section{Results}

\section{Preparation of cell suspensions}

After trying various methods, including EDTA (Davis \& Schuetz, 1975) or dispase (S.K. Grund \& L.J. Pelliniemi, unpublished), we chose the collagenase/trypsin treatment of the testes as the method of choice to obtain a maximum number of viable cells $(95 \%)$. Furthermore, the frequency of clumps or multinucleate cells was minimal (5-7\% of the total cell suspension). 
The initial collagenase digestion did not release interstitial cells from the seminiferous cords as efficiently as it did from testes of older animals (Bellve et al., 1977; Bucci et al., 1986). Nevertheless, it was still included because it did render the testis more susceptible to disruption by the subsequent trypsin treatment. Centrifugation of the collagenase-treated testes was also performed to avoid incubating the cells for too long with the same enzyme.

\section{Choice of optimal age for obtaining gonocytes}

As shown in Table 1, the testes of newborn rats are $3 \cdot 5$-fold heavier than the fetal testes. This is mainly due to the increase in the number of supporting (precursors of Sertoli) cells, which start proliferating from 18 days p.c. onwards (Sapsford, 1962; Hilscher \& Makoski, 1968) (compare also Figs $1 \mathrm{a}$ and $\mathrm{b}$ ). As a consequence, the cell yield per testis is higher in the newborn testes. However, the percentage of gonocytes in the suspension decreases abruptly in the newborn testes, and consequently the total number of gonocytes recovered per testis was lower in the fetal testes. Fetal testes were therefore chosen for the separation of gonocytes.

Table 1. Cell populations recovered from rat testes after dispersion with collagenase and trypsin (average numbers and standard deviation of 6 experiments for each age class)

\begin{tabular}{|c|c|c|}
\hline & \multicolumn{2}{|c|}{ Age of rat } \\
\hline & $\begin{array}{c}18 \text { days } \\
\text { post coitum }\end{array}$ & Newborn \\
\hline Wet weight/testis (mg) & $0.8 \pm 0 \cdot 1$ & $3 \cdot 2 \pm 0 \cdot 6$ \\
\hline $\begin{array}{l}\text { Cells recovered/testis } \\
\left(\times 10^{-5}\right)\end{array}$ & $1.5 \pm 0.8$ & $5 \cdot 7 \pm 1 \cdot 4$ \\
\hline$\%$ Gonocytes & $22 \pm 4$ & $1 \pm 1$ \\
\hline $\begin{array}{l}\text { Gonocytes recovered/ } \\
\text { testis }\left(\times 10^{-3}\right)\end{array}$ & $27 \pm 7$ & $7 \pm 5$ \\
\hline
\end{tabular}

\section{Cell separation}

Gonocytes are larger than other testicular cells in fetal testes (Figs 1 and 3a). Hence, after separation, one should expect to find a distinct population of cells with a higher velocity of sedimentation than the rest. Indeed, with a cell suspension from fetal testes, a population of cells could be discerned with a sedimentation velocity around $12 \mathrm{~mm} / \mathrm{h}$ (Fig. 2a). This population consisted of $70-75 \%$ gonocytes as compared to the starting material which contained only $24 \%$ gonocytes (Fig. 2b). Separation by velocity sedimentation did not cause any cell loss: the total cell recovery was comparable to the number of cells in the starting suspension $\left(10^{7}\right.$ cells). Furthermore, the percentage of cells excluding Trypan blue remained high after this separation procedure (95-99\%). Attempts to obtain higher purity of gonocytes by subsequent separation by equilibrium density centrifugation on Percoll gradients (Meistrich et al., 1981) yielded no further enrichment in gonocytes (results not shown).

\section{Characterization of the cells}

The morphology of the separated cells was analysed by Nomarski interference microscopy. Figure 3(a) shows an unseparated cell suspension from fetal testes in which cells of different sizes can be seen. After separation, cells of similar volumes are obtained in the different fractions. Figure 

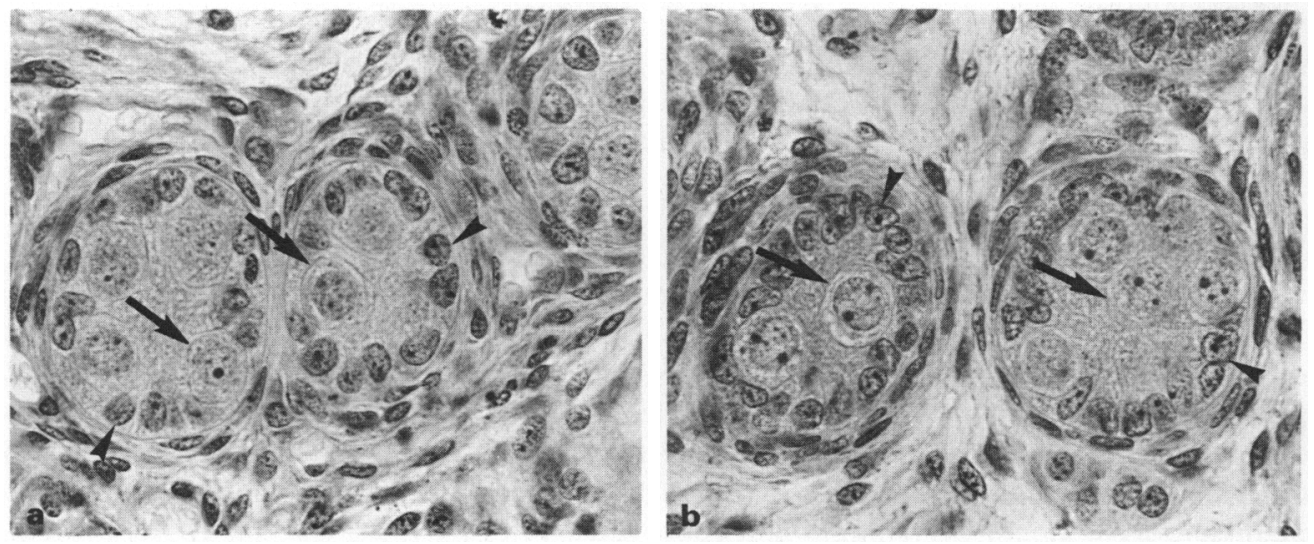

Fig. 1. Photomicrographs of a testis cross-section from (a) an 18-day p.c. fetal rat and (b) a newborn rat. Within the sex cords, the Sertoli cells (arrowheads) are at the periphery, while the germ cells (arrows) are situated in the centre. Note the number of gonocytes (mean \pm s.e.m.) as compared to the number of Sertoli cells per tubular cross section at both ages $(14 \pm 1 \%$ in fetal rats as compared to $5 \pm 1 \%$ in newborn rats, 100 cross-sections scored for each age). $\times 680$.

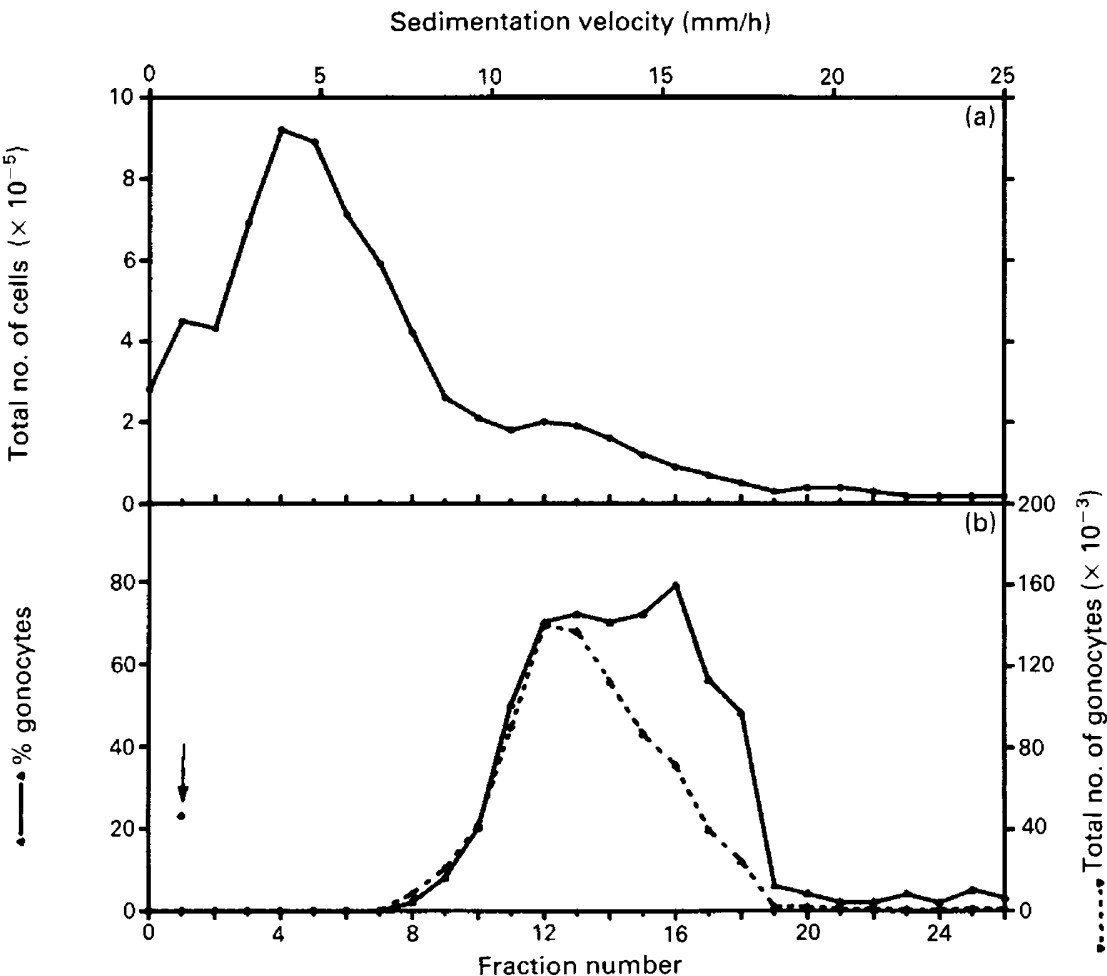

Fig. 2. Separation of testicular cells from an 18-day p.c. fetal rat by velocity sedimentation: (a) distribution of cells according to their sedimentation rates; (b) percentage and total number of gonocytes in the different fractions obtained. 

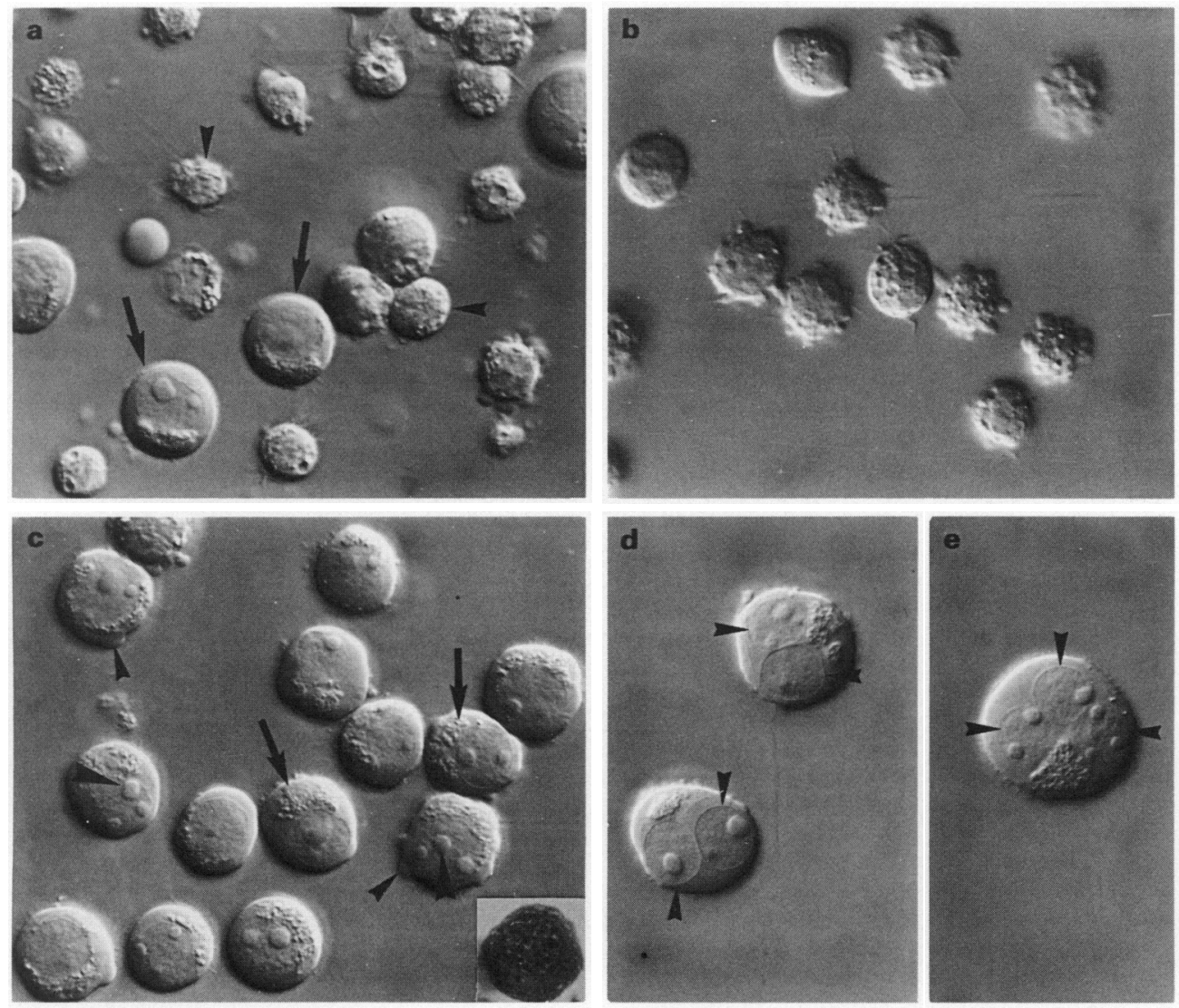

Fig. 3. Nomarski differential interference photomicrographs of fetal rat testicular cells before and after separation by velocity sedimentation (a) Suspension of dispersed testicular cells before separation, gonocytes (arrows), others (arrowheads). (b) Cells with small volume, found in Fractions 5-9 after separation. (c) A fraction containing $>75 \%$ gonocytes. Note the cytoplasmic inclusions (arrows) at one side of the cells, the nucleoli (large arrowheads) and the blebs (small arrowheads); inset: a gonocyte fixed in Bouin's solution, embedded in glycol methacrylate and stained with haematoxylin. (d) and (e) Samples of binucleate and trinucleate gonocytes respectively, recovered in Fractions 21-26 after separation. The different nuclei are shown with arrowheads. $\times 700$.

3(b) shows small cells, which sediment in the first 5-9 fractions. These cells are probably fetal Sertoli cells and interstitial cells, but could not be further characterized morphologically. An example of the morphology of the gonocytes is shown in Fig. 3(c). Sometimes these cells showed blebs (small arrowheads) but usually they had a smooth plasma membrane. The inset in this figure shows the morphology of isolated gonocytes when fixed, embedded in plastic and stained with haematoxylin. By comparing the isolated cells with gonocytes from the testis sections in Figs 1(a) and 1(b), it is clear that they are indeed gonocytes: large round cells, with high nuclear to cytoplasmic ratio, granulated chromatin and distinct nucleolus. Figures 3(d) and 3(e) show examples of multinucleate gonocytes, which are present, along with clumps, in the late fractions containing rapidly sedimenting material. Figure 4(a) shows the volume distributions of the total cell suspensions of fetal testis cells. The cell suspension contains a subpopulation of cells with a larger volume than the rest, at about $1400 \mu \mathrm{m}^{3}$. This subpopulation must represent the gonocytes, based on their large size. Indeed, Fractions 11-16, known to be enriched in gonocytes by Nomarski microscopy, 


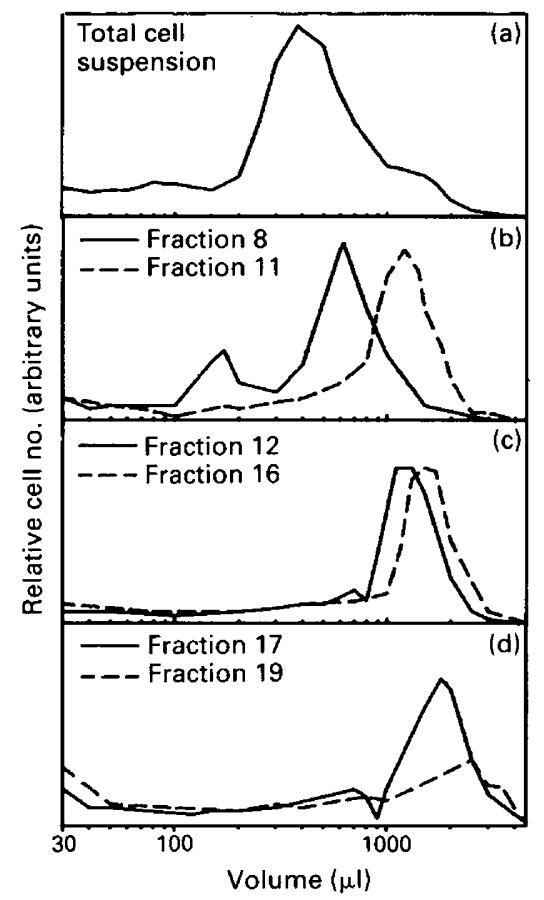

Fig. 4. Volume distributions of unseparated (a) and separated (b), (c) and (d) cells from fetal testes at 18 days p.c.

showed a well-defined peak of cells at around $1400 \mu \mathrm{m}^{3}$ (Figs $4 \mathrm{~b}$ and $4 \mathrm{c}$ ). From Fraction 17 onwards (Fig. 4d) there was an increase in the proportion of cells above $2500 \mu \mathrm{m}^{3}$, representing symplasts and clumps of cells.

\section{Discussion}

With the method described in this paper, it is possible to isolate successfully a highly enriched population of viable gonocytes from rat fetuses at 18 days p.c.

An important factor, which had to be considered first in this study, was the age of the rats with which experiments were going to be performed. Although newborn rats are easier to handle than fetal rats, they appeared to be less suitable for the separation of gonocytes. With the isolation procedures described in this study no useful purification of gonocytes from newborn testes could be obtained. The decrease ( $26 \%$ of the total number of gonocytes obtained per fetal testis) in the numbers of gonocytes could have been due to degeneration of many of these cells shortly after birth as has been described previously (Sapsford, 1962; Franchi \& Mandl, 1964; Huckins \& Clermont, 1968; Roosen-Runge \& Leik, 1968; Hilscher et al., 1974). However, it is also possible that the gonocytes in the newborn, as they undergo ultrastructural changes before resuming mitosis (Roosen-Runge \& Leik, 1968), become more sensitive to the enzymic treatment. Furthermore, the increased number of Sertoli cells in the newborn testis might impede the complete release of the gonocytes, thereby leading to lower yields of gonocytes in the cell suspensions.

The second important consideration in the procedure was the preparation of the cell suspension. The digestion of the testes to single cells is important since separation is based on size, and aggregates of smaller cells will contaminate the fraction of the gonocytes. The collagenase/trypsin method seemed to give the best results. Although interstitial cells could not adequately be removed after the collagenase treatment, this was not of great consequence since gonocytes are larger cells 
than the bulk of the testicular cells at that age. After the trypsin treatment only a few cell clumps could be seen in the cell suspension. Furthermore, the frequency of multinucleate gonocytes which form by opening up of the intercellular bridges that exist between these cells (Zamboni \& Merchant, 1973; Hilscher et al., 1974), and which may also be detrimental for the purification of cells by velocity sedimentation (Meistrich, 1977), was minimal. In this respect, it was important to treat the tissue gently before and during enzymic treatment as the formation of symplasts in cell suspensions is due to handling of the tissue (Romrell et al., 1976).

The viability of the cells was the third point to take into account. Although dissection of the fetal testes took about $3 \mathrm{~h}$, and the whole procedure $8 \mathrm{~h}$, the percentage of degenerating cells as assessed by Nomarski microscopy and Trypan blue exclusion, never exceeded $5 \%$. The ultimate test of viability of these cells, their ability to proliferate and differentiate in culture, is precluded by the absence of a suitable culture system. In preliminary experiments, however, we have been able to maintain the gonocytes intact in vitro for long periods of time, as determined by their adherence to a monolayer of Sertoli cells onto which they were cultured. This indicates that the isolated gonocytes were indeed viable.

Finally, the accurate identification of the isolated cells was very important. In this study, we used cytological identification by Nomarski microscopy and by embedding and staining the isolated cells in the manner that testicular tissue is processed for histological examination, in conjunction with cell volume determination. Both methods gave complementary information that demonstrated that the cells obtained were gonocytes. Gonocytes could be purified to $70-75 \%$ by velocity sedimentation at unit gravity. The purity and the numbers of gonocytes obtained after separation of fetal testicular cells now provide an opportunity to study the biochemistry and in-vitro behaviour of these cells.

We thank Patricia Trostle Weige for encouraging support during this study. This research was supported by the Dutch Organization for the Advancement of Fundamental Research (Z.W.O.), grant no. R91-168 and grant no. HD-16843 from the National Institutes of Health, USA.

\section{References}

Bellve, A.R., Cavicchia, J.C., Millette, C.F., O'Brien, D.A., Bhatnagar, Y.M. \& Dym, M. (1977) Spermatogenic cells of the prepuberal mouse. Isolation and morphological characterization. J. Cell Biol. 74, 68-85.

Bucci, L.R., Brock, W.A., Johnson, T.S. \& Meistrich, M.L. (1986) Isolation and biochemical studies of enriched populations of spermatogonia and early primary spermatocytes from rat testes. Biol. Reprod. 34, 195-206.

Davis, J.C. \& Schuetz, A.W. (1975) Separation of germinal cells from immature rat testes by sedimentation at unit gravity. Expl Cell Res. 91, 79-86.

De Felici, M. \& McLaren, A. (1982) Isolation of mouse primordial germ cells. Expl Cell Res. 142, 476-482.

Franchi, L.L. \& Mandl, A.M. (1964) The ultrastructure of germ cells in foetal and neonatal male rats. $J$. Embryol. exp. Morph. 12, 2, 289-308.

Hilscher, W. \& Makoski, H.B. (1968) Histologische und autoradiographische untersuchungen zur 'präspermatogenese' und 'spermatogenese' der ratte. $Z$. Zellforsch. mikrosk. Anat. 86, 327-350.

Hilscher, B., Hilscher, W., Bulthoff-Ohnolz, B., Kramer, U., Birke, A., Pelzer, H. \& Gauss, G. (1974) Kinetics of gametogenesis. I. Comparative histological and autoradiographic studies of oocytes and transitional prospermatogonia during oogenesis and prespermatogenesis. Cell Tiss. Res. 154, 443-470.
Hilscher, W. (1981) $T_{1}$-prospermatogonia (primordial spermatogonia of Rauh): the 'ameiotic' counterpart of early oocytes. Fortsch. Androl. 7, 21-32.

Huckins, C. \& Clermont, Y. (1968) Evolution of gonocytes in the rat testis during late embryonic and early post-natal life. Archs Anat. Hist. Embryol. 51, 343-354.

Kluin, Ph.M. \& de Rooij, D.G. (1981) A comparison between the morphology and cell kinetics of gonocytes and adult type undifferentiated spermatogonia in the mouse. Int. J. Androl. 4, 475 493.

McCarrey, J.M., Hsu, K.C., Eddy, E.M., Klevecz, R.R. \& Bolen, J.L. (1987) Isolation of mouse primordial germ cells by antibody-directed flow sorting. $J$. exp. Zool. 242, 107-111.

Meistrich, M.L. (1977) Separation of spermatogenic cells and nuclei from rodent testes. In Methods in Cell Biology, Vol. 15, pp. 15-24. Ed. D. M. Prescott. Academic Press, New York.

Meistrich, M.L., Longtin, J., Brock, W.A., Grimes, S.R., Jr \& Mace, M.L. (1981) Purification of rat spermatogenic cells and preliminary biochemical analysis of these cells. Biol. Reprod. 25, $1065-1077$.

Romrell, L.J., Bellve, A.R. \& Fawcett, D.W. (1976) Separation of mouse spermatogenic cells by sedimentation velocity. A morphological characterization. Devl Biol. 49, 119-131. 
Roosen-Runge, E.C. \& Leik, J. (1968) Gonocyte degeneration in the postnatal male rat. Am. J. Anat. 122, 275-299.

Sapsford, C.S. (1962) Changes in the cells of sex cords and seminiferous tubules during development of the testis of the rat and mouse. Aust. J. Zool. 10, 178-192.
Zamboni, L. \& Merchant, H. (1973) The fine morphology of mouse primordial germ cells in extragonadal locations. Am. J. Anat. 137, 3, 299-334.

Received 26 January 1989 